\title{
Islet cell cytoplasmic antibody reactivity in midgestational human fetal pancreas
}

\author{
R.R. de Krijger ${ }^{1}$, M.V. van Krugten ${ }^{1}$, G. Kranenburg ${ }^{1}$, H. J. Aanstoot ${ }^{1}$, J. L. Molenaar ${ }^{2}$, and G. J. Bruining ${ }^{1}$ \\ 1 Department of Pediatrics and Clinical Genetics, Erasmus University and University Hospital/Sophia Children's Hospital, \\ Dr. Molewaterplein 60, 3015 GJ Rotterdam, The Netherlands \\ 2 Department of Clinical Immunology, SSDZ, Delft, The Netherlands
}

Received: 25 November 1993 / Accepted in revised form: 14 July 1994

\begin{abstract}
The reactivity of islet cell cytoplasmic antibodies (ICA)-positive and ICA-negative sera of recent onset type 1 diabetic patients was studied in human fetal pancreata of 12-18 weeks' gestation and compared with the reactivity of these sera in adult human control pancreata. The aims of the study were: (1) to observe the presence of ICA staining in human fetal islet cells; (2) to compare endpoint titres (in Juvenile Diabetes Foundation units) of ICA-positive patient sera in fetal pancreata and adult human control pancreata. Ten ICA-positive sera and eight ICA-negative sera from newly diagnosed diabetic patients and four sera from healthy controls were tested on three human adult and eight human fetal pancreata. As in the adult control pancreata. ICA-positive sera reacted to insulin-, glucagon-, and somatostatin-positive cells of fetal pancreata of all gestational ages. This was observed both in single cells and in cells in islet-like cell clusters. Dilution of a reference serum gave similar results in both adult and fetal pancreata. In contrast, the ICApositive patient sera yielded a striking heterogeneity in fetal as well as in adult pancreata. However, end-point titres between adult and fetal pancreata did not differ significantly $(P>0.05)$. In conclusion, ICA-positive sera from recent onset diabetic patients show that the expression of molecules to which ICA react is present in all islet cells and starts before week 12 of gestation.
\end{abstract}

Key words: Islet cell antibody - Human fetal pancreas Indirect immunofluorescence - Humoral autoimmunity

\section{Introduction}

Humoral autoimmunity to pancreatic islet cells can be detected in sera of recent-onset type 1 (insulin-dependent) diabetic patients and in sera of prediabetic individuals before clinical onset of type 1 diabetes [1]. Islet cell cytoplasmic antibodies (ICA) have been studied exten-

Correspondence to: G.J. Bruining sively. They are detected by indirect immunofluorescence of cryostat sections of blood group 0 human adult pancreata. ICA-positive sera usually stain $\alpha, \beta$, and $\delta$ cells in the islets of Langerhans ("whole islet staining pattern") [2]. The assay has been standardized through the use of reference sera [3]. Multiple islet cell antigens have been suggested as ICA targets including glutamic acid decarboxylase (GAD) [4-6]. Apart from the whole islet staining pattern of ICA-positive sera, a restricted pattern, in which only $\beta$ cells are stained, has been observed [7].

In experimental studies it has been shown that the onset of autoimmunity depends on the timing of antigen expression during fetal development [8]. It is therefore of interest to study human fetal antigen expression, using ICA-positive patient sera. Limited information is available on the reactivity of ICA to human fetal pancreatic tissue [9]. This tissue contains endocrine cells at various stages of development, being present as single cells or organized in smaller or larger endocrine cell clusters [10]. In one study a single ICA-positive serum and a single ICA-negative serum were tested [9]. Only insulin/ICA double-staining was evaluated. The other endocrine cell types were not analyzed. No comparison was made with adult pancreata. In the present study, the ICA staining pattern in all major islet cell types was investigated. Endpoint titres [in Juvenile Diabetes Foundation (JDF) units] of a series of ICA-positive sera were determined in fetal and adult control pancreata.

\section{Materials and methods}

Sera. Serum samples were obtain within $24 \mathrm{~h}$ of the first insulin injection from 18 type 1 diabetic patients (aged 8-20 years, mean 14 years; four boys and six girls). The ICA-positive samples $(n=10)$ were selected to represent a range from weakly to strongly positive for ICA, as tested with an adult pancreas. The cut-off point for the distinction between an ICA-positive and an ICA-negative patient serum was $0.63 \mathrm{JDF}$ unit. All sera were ICA-IgG positive, and six showed complement fixation ability (CF-ICA) [11]. Insulin autoantibodies (IAA) in these samples were absent according to radioimmunoassay, RIA [12], as well as enzyme-linked immunosorbent assay, ELISA [13]. Control sera were obtained from four healthy 
individuals. No control had a first-degree relative with insulin dependency. Serum samples were stored at $-80^{\circ} \mathrm{C}$.

Human fetal pancreata. Human fetal pancreata (blood group 0) between 12 and 18 weeks gestation $(n=8)$ were obtained from mechanical abortion, approved by the local ethical committee, and with signed informed consent. The warm ischemia time was less than $20 \mathrm{~min}$. After collection, the pancreata were snap-frozen in liquid nitrogen and stored at $-80^{\circ} \mathrm{C}$. Blood group typing was performed on spleen cells.

Human adult pancreata. Blood group 0 pancreata were obtained from three donors. The pancreas was removed first. The adult pancreata were divided into pieces of $0.5 \mathrm{~cm}^{3}$, snap-frozen in liquid nitrogen, and stored at $-80^{\circ} \mathrm{C}$.

Immunohistochemistry. The methods used have been described previously [14, 15]. Briefly, cryostat sections were incubated for $18 \mathrm{~h}$ with serum (diluted $1: 2$ to $1: 1024$ ) in phosphate-buffered saline (PBS). Aprotinin (Trasylol, Sigma Chemical Co., St. Louis) $0.47 \mathrm{mg} / \mathrm{ml}$ was added to prevent proteolytic degradation of the pancreatic tissue. Incubations were performed in a dark-moist chamber at room temperature. Slides were washed in PBS, and double staining was carried out with a mouse anti-human proinsulin monoclonal antibody (GS4G9, dilution 1:10, a gift of Dr. O.D. Madsen, Gentofte, Denmark) for $30 \mathrm{~min}$. Slides were again washed in PBS, and the sections were incubated with a TRITC-labelled rabbit anti-mouse IgG 1:100 (PBS) (Dako, Copenhagen, Denmark) for $30 \mathrm{~min}$. Finally, fluoreseein isothiocyanate (FITC)conjugated rabbit anti-human $\mathrm{IgG}$ (Dako) was added in a dilution of 1:100 for $30 \mathrm{~min}$, to detect ICA. Antibodies to glucagon (GLU001, 1:30, Novo, Bagsvaerd, Denmark) or somatostatin (SOM-018, $1: 1000$, Novo) were used for double staining instead of the proinsulin antibody to detect the other endocrine cell types. Both were mouse monoclonal antibodies.

Sera were diluted stepwise, until reciprocal titers of 1024 , generating 10-point titration curves. The reciprocal endpoint titre was defined as the maximal dilution at which fluorescence could be detected by two independent observers. A reference serum (80 JDF units $/ \mathrm{ml}$ ) was used on all pancreata studied (three adult, eight fetal), by diluting to four different concentrations $(1: 2,1: 8,1: 32$, and $1: 128$ ) in normal ICA-negative serum [3]. These four concentrations were further diluted to obtain final reciprocal titers between $1: 4$ and 1:16 384. Linear titration curves were obtained. The limited amount of fetal tissue available and the unknown sensitivity of these pancreata for the ICA sera were reasons to deviate from ICA workshop recommendations. Transformation from endpoint titre to JDF units was based on reciprocal endpoint titre of the reference serum on each pancreas.
Statistical analysis. Differences in endpoint titre between adult and fetal pancreata were analyzed by the Mann-Whitney U-test.

\section{Results}

We have previously described the histologic features of the human midgestational pancreas using antibodies to insulin, glucagon, and somatostatin [10]. In accordance with that study, positive single cells and cell clusters of varying sizes were observed for all three hormones tested and in all eight fetal pancreata used for this study.

Reciprocal endpoint titres and corresponding JDF units of ICA for the adult and fetal pancreata are indicated in Table 1. In three fetal pancreata (F1, F2, F6), the limited amount of tissue prohibited the testing of some of the sera. In pancreata F2, F3, F7, and F8, one ICA-positive serum did not react, whereas in pancreas $F 1$, two sera did not react (see Table 1). In the adult pancreata, two sera did not react to pancreas A3, whereas all sera showed ICA staining on the other two adults pancreata.

Double staining of sections, combining ICA sera with antibodies to insulin, glucagon, and somatostatin, showed that all three cell types express ICA targets (Fig. 1). In addition to ICA-reactive endocrine cell clusters, single-hormone-containing cells were also stained (Fig. 2). In all pancreata and with all ICA-positive sera, the "whole islet staining pattern" was observed [2], whereas $\beta$-cell-restricted ICA staining was not seen in this study. No hormone-negative cells reacted with ICA-positive sera in either the fetal or adult pancreata.

The results of testing and titrating the reference serum and its dilutions are shown in Table 2. All three adult pancreata had identical reciprocal endpoint titres. The endpoint titre of the reference serum in fetal pancreata $\mathrm{F} 1, \mathrm{~F} 4$, and $\mathrm{F} 5$ was one dilution step lower, whereas the difference was two steps in pancreata F7 and F8. The results of the 10 patient sera were highly heterogeneous, for the three adult as well as the eight fetal pancreata. With sera 6,7, and 10, pancreas A1 showed titres which were 5,4 , and 4 dilution steps lower than for the same sera with pancreas A2, respectively. With sera $3,4,8$, and

Table 1. Reciprocal endpoint titres and transformation into JDF units (in parentheses) of 10 sera of recent-onset diabetic patients for three adult and eight fetal human pancreata

\begin{tabular}{|c|c|c|c|c|c|c|c|c|c|c|}
\hline $\begin{array}{l}\text { Pancreas } \\
\text { (weeks of } \\
\text { gestation) }\end{array}$ & \multicolumn{10}{|c|}{ Serum number } \\
\hline $\mathrm{A} 2$ & $16(5)$ & $16(5)$ & $4(1.25)$ & $64(20)$ & $16(5)$ & $1024(320)$ & $128(40)$ & $32(10)$ & $256(80)$ & $128(40)$ \\
\hline A3 & $0(0)$ & $0(0)$ & $2(0.63)$ & $64(20)$ & $8(2.5)$ & $512(160)$ & $128(40)$ & $8(2.5)$ & $32(10)$ & $32(10)$ \\
\hline $\mathrm{F} 1(12)$ & $0(0)$ & $0(0)$ & NT & $8(2.5)$ & $8(2.5)$ & NT & $8(10)$ & NT & NT & NT \\
\hline F4 (13) & $8(2.5)$ & $8(2.5)$ & $8(2.5)$ & $32(10)$ & $8(2.5)$ & $128(40)$ & $16(5)$ & $4(1.25)$ & $64(20)$ & $32(10)$ \\
\hline F5 (14) & $4(1.25)$ & $8(2.5)$ & $8(2.5)$ & $64(20)$ & $4(1.25)$ & $128(40)$ & $64(20)$ & $32(10)$ & $128(40)$ & $16(5)$ \\
\hline F6 (14) & $8(2.5)$ & $8(2.5)$ & $16(5)$ & $32(10)$ & $16(5)$ & NT & NT & $\mathrm{NT}$ & $\mathrm{NT}$ & $\mathrm{NT}$ \\
\hline F7 (15) & $0(0)$ & $8(2.5)$ & $4(1.25)$ & $16(5)$ & $8(2.5)$ & $128(40)$ & $32(10)$ & $4(1.25)$ & $64(20)$ & $2(0.63)$ \\
\hline F8 (17) & $8(2.5)$ & $8(2.5)$ & $4(1.25)$ & $32(10)$ & $8(2.5)$ & $128(40)$ & $32(10)$ & $16(5)$ & $64(20)$ & $0(0)$ \\
\hline
\end{tabular}

0 , Negative; NT, not tested; A, adult pancreas; F, fetal pancreas (gestational age in weeks indicated in brackets) 

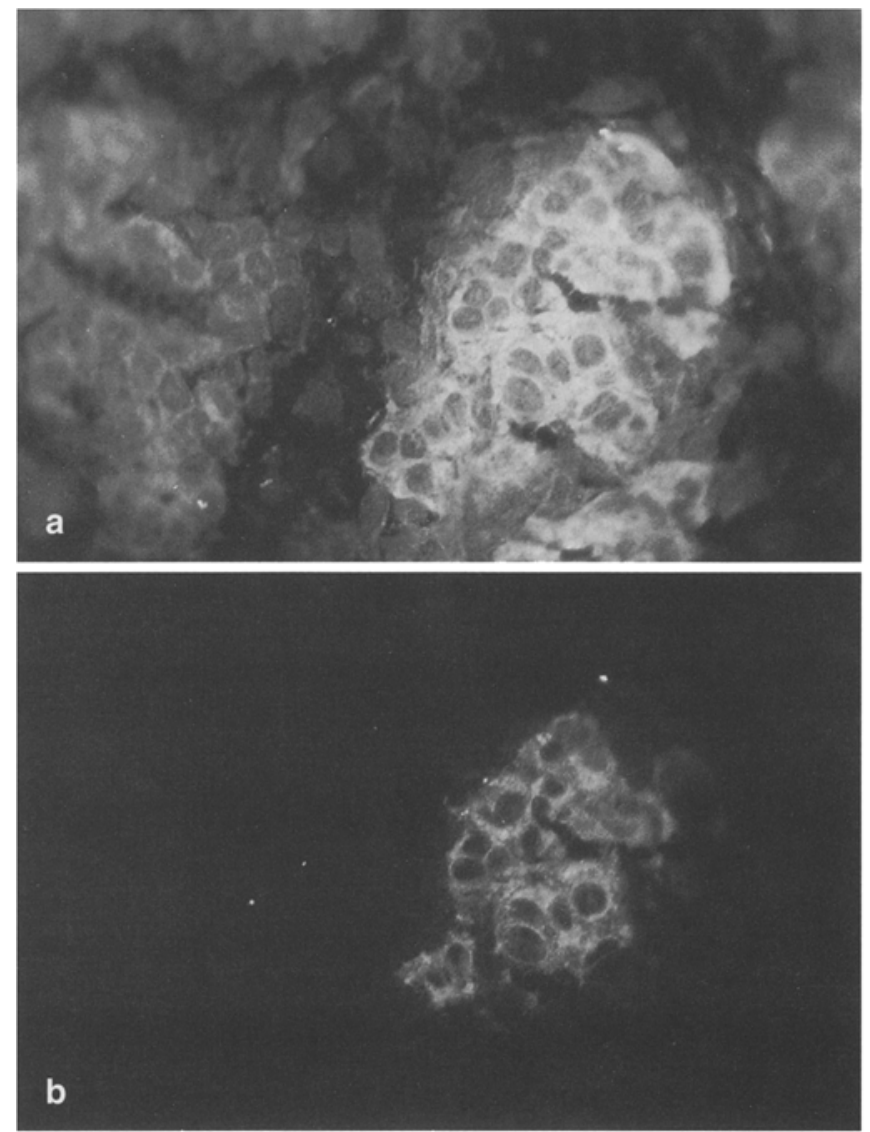

Fig. 1 a, b. Immunofluorescence photographs of an identical area in a human fetal pancreatic section double-stained with an ICApositive serum (a) and with a monoclonal proinsulin antibody (b). Note that ICA reactivity is present in cells surrounding the proinsulin-positive cell core

Table 2. Reciprocal endpoint titres of the reference serum for adult (A) and fetal (F) pancreata

\begin{tabular}{lrrrrl}
\hline $\begin{array}{l}\text { Pancreas } \\
\text { (weeks of } \\
\text { gestation) }\end{array}$ & $\begin{array}{l}\text { Reference } \\
\text { serum }\end{array}$ & \multicolumn{3}{c}{ Reference serum dilution } \\
\cline { 3 - 6 } & & $1: 2$ & $1: 8$ & $1: 32$ & $1: 128$ \\
\hline A1 & 256 & 128 & 32 & 8 & 2 \\
A2 & 256 & 128 & 32 & 8 & 2 \\
A3 & 256 & 128 & 32 & 8 & 2 \\
F1 (12) & 64 & 32 & 8 & 2 & 0 \\
F2 (13) & 256 & 128 & 32 & 32 & 8 \\
F3 (13) & 256 & 128 & 32 & 8 & 2 \\
F4 (13) & 64 & 32 & 8 & 2 & 2 \\
F5 (14) & 64 & 32 & 8 & 2 & 2 \\
F6 (14) & 256 & 128 & 32 & 2 & 2 \\
F7 (15) & 16 & 8 & 2 & 2 & 0 \\
F8 (17) & 16 & 8 & 2 & 2 & 0 \\
\hline
\end{tabular}

9 , however, titres were similar or even 1 or 2 dilution steps higher. Serum 9 gave a 5-dilution-steps lower titre in pancreas $F 2$ than in pancreas F3, whereas with serum 7 , pancreas F2 had a two-step higher titre. No significant differences in endpoint titre between adult and fetal pancreata could be detected $(P>0.05)$.
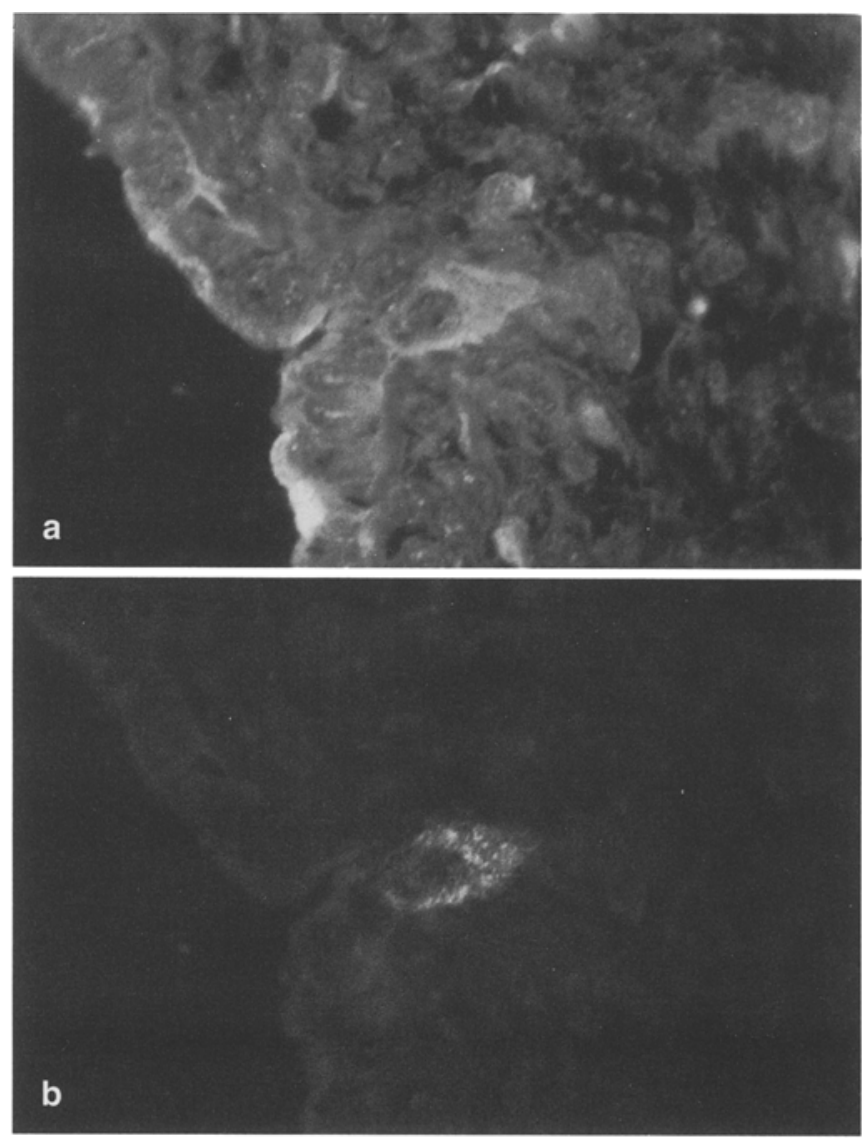

Fig. 2a, b. Immunofluorescence photographs of an identical area in a human fetal pancreatic section double-stained with an ICApositive serum (a) and with a monoclonal proinsulin antibody (b). Co-expression of proinsulin and ICA reactivity can be observed in a single endocrine cell

Of the eight sera of recent-onset diabetic patients which tested ICA-negative on adult pancreata, two were found reactive to pancreas $\mathrm{F} 3$ and $\mathrm{F} 5$, one other serum reacted to pancreas $\mathrm{F} 6$, all at a dilution of $1: 2(0.63 \mathrm{JDF}$ units). None of the four healthy control sera reacted to either adult or fetal pancreata.

\section{Discussion}

We confirm the observation of Sundkvist et al. [9] that ICA reactivity is present in the human fetal pancreas. ICA reactivity is found in all fetal pancreata between 12 and 18 weeks' gestation, indicating that expression of molecules to which ICA react starts before week 12 of gestation. The ICA reactivity includes all insulin-, glucagon-, as well as somatostatin-positive cells, consistent with findings in the adult pancreas [16]. In this study, no $\beta$-cell-restricted ICA reactivity pattern is found. In human fetal pancreata, ICA reactivity is seen in endocrine cell clusters and in single-hormone-containing cells. Thus, ICA reactivity does not mark the different stages of endocrine cell development during the 12-18week period. This is supported by the finding that the staining pattern is quite similar in the different fetal pan- 
creata. We have not examined hormone co-expressing cells in which two or three hormones are present simultaneously, as shown to be present during endocrine cell ontogeny [10]. Triple labelling studies should be used to analyze whether or not the multiple-hormone-expressing cells also exhibit ICA reactivity. Analysis of reference serum reactivity on adult pancreata gives an identical result at each dilution in each of the three pancreata. When our 10 diabetic sera are applied, however, heterogeneous endpoint titres and corresponding JDF units are obtained. This variability in adult pancreata has been described before [17].

In the fetal pancreata, dilution of the reference serum yields endpoint titres comparable to those of the adult pancreata. Heterogeneous results are obtained in the fetal pancreata with the patient sera. This does not lead to significant differences in endpoint titres between adult and fetal pancreata. The differences in reactivity of ICApositive sera between fetal pancreata may be explained by the fact that ICA react to multiple target molecules which are not present in equal amounts during development $[7,18]$. During fetal development, islet cells are present at differing developmental stages, which may affect the antigenic profile qualitatively and quantitatively. In addition, the metabolic state of endocrine cells, which is unknown in our fetal islet cells, has been shown to influence antigen expression [19]. No conclusion can be drawn with regard to the effect of antigenic heterogeneity in fetal pancreata on ICA titre, because this study did not address ICA reactivity to defined antigens. Further molecular identification of ICA epitopes in the human fetal pancreas is essential.

Acknowledgements. R.R. de K. is supported by a grant from the Diabetes Fonds Nederland, The Netherlands. H.J.A. is supported by a grant from the Ter Meulen Foundation of the Royal Dutch Academy of Sciences and the A. Renold Fellowship of the European Association for the Study of Diabetes. M.V. van K. took part in the Erasmus University Medical Student Research Training Program.

\section{References}

1. Bruining GJ, Molenaar JM, Grobbee DE, Hofman A, Scheffer GJ, Bruining HA, De Bruyn AM, Valkenburg HA, Ten-year follow-up study of islet cell antibodies and childhood diabetes mellitus. Lancet: $1100-1103,1989$

2. Atkinson MA, Kaufman DL, Newman D, Tobin AJ, MacLaren $\mathrm{NK}$, Islet cell cytoplasmic autoantibody reactivity to glutamate decarboxylase in insulin-dependent diabetes. J Clin Invest 91:350-356, 1993

3. Greenbaum C, Palmer J, Nagataki S, Yamaguchi Y, Molenaar JL, Van Beers WAM, MacLaren NK, Lernmark $\AA$, and partic- ipating laboratories, Improved specificity of ICA assays in the fourth international immunology of diabetes serum exchange workshop. Diabetes 41:1570-1574, 1992

4. Nayak RC, Omar AK, Rabizadeh A, Srikanta S, Eisenbarth GS, Cytoplasmic isiet cell antibodies; evidence that the target antigen is a sialoglyco-conjugate. Diabetes 34:617-619, 1985

5. Colman PG, Nayak RC, Campbell IL, Eisenbarth GS, Binding of cytoplasmic islet cell antibodies is blocked by human pancreatic glycolipid extracts. Diabetes 37:645-652, 1988

6. Pietropaolo M, Castaño L, Babu S, Buelow R, Kuo YL, Martin S, Martin A, Powers AC, Prochazka M, Naggert J, Leiter $\mathrm{EH}$, Eisenbarth GS, Islet cell autoantigen $69 \mathrm{kD}$ (ICA69). Molecular cloning and characterization of a novel diabetes-associated autoantigen. J Clin Invest 92:359-371, 1993

7. Genovese S, Bonifacio E, McNally JM, Dean BM, Wagner R, Bosi E, Gale EAM, Bottazzo GF, Distinct cytplasmic islet cell antibodies with different risks for type I (insulin-dependent) diabetes mellitus. Diabetologia 35:385-388, 1992

8. Adams TE, Alpert $S$, Hanahan D, Non-tolerance and autoantibodies to a transgenic self antigen expressed in pancreatic beta cells. Nature 325:223-228, 1987

9. Sundkvist $G$, Bergqvist A, Weibull $H$, Bergqvist D, Fält $K$, Landin Olsson $M$, Lernmark $\AA$, Islet cell antibody reactivity with human fetal pancreatic islets. Diabetes Res Clin Pract 14:1-8, 1991

10. RR Krijger de, Aanstoot HJ, Kranenburg G, Reinhard M, Visser WJ, Bruining GJ, The midgestational human fetal pancreas contains cells coexpressing islet hormones. Dev Biol 153:368-375, 1992

11. Bruining GJ, Molenaar J, Tuk CW, Lindeman J, Bruining HA, Marner B, Clinical time-course and characteristics of islet-cell cytoplasmic antibodies in childhood diabetes. Diabetologia 26:24-29, 1984

12. Palmer JP, Asplin CM, Clemons P, Lyen K, Tatpati O, Raghu PK, Paguette TL, Insulin antibodies in insulin-dependent diabetics before insulin treatment. Science 222:1337-1339, 1983

13. Wilkin T, Armitage M, Casey C, Pyke DA, Hoskin PJ, Rodier M, Diaz JC, Leslie RDG, Value of insulin auto-antibodies as serum markers for insulin-dependent diabetes mellitus. Lancet I: 480-482, 1985

14. Madsen OD, Landin-Olsson $M$, Bille $G$, Sundkvist $G$, Lernmark $\AA$, Dahlqvist G, Ludvigsson J, A two-colour immunofluorescence test with a monoclonal human proinsulin antibody improves the assay for islet cell antibodies. Diabetologia 29:115-118, 1986

15. Landin-Olsson M, Sundkvist G, Lernmark $\AA$, Prolonged incubation in the two-colour immunofluorescence test increases the prevalence and titre of islet cell antibodies in Type 1 (insulin-dependent) diabetes mellitus. Diabetologia 30:327-332, 1987

16. Bottazzo GF, Doniach D, Islet-cell antibodies (ICA) in diabetes mellitus. Evidence of an autoantigen common to all cells in the islet of Langerhans. Ric Clin Lab 8:29-39, 1978

17. Landin-Olsson M, Sundkvist G, Lernmark $\AA$, Precision of isletcell antibody assay depends on the pancreas. Diabetologia 31: 511(A), 1988

18. Nayak RC, Omar MAK, Rabizadeh A, Srikanta S, Eisenbarth GS, "Cytoplasmic" islet cell antibodies: evidence that the target antigen is a sialoglycoconjugate. Diabetes 28:617-619, 1985

19. McCulloch DK, Barmeier H, Neifing JL, Palmer JPP, Metabolic state of the pancreas affects end-point titre in the islet cell antibody assay. Diabetologia $34: 622-625,1991$ 